\title{
PERANAN PENDIDIKAN AGAMA ISLAM DALAM PEMBINAAN MORAL GENERASI MUDA
}

\author{
Narjun Bahmid
}

\begin{abstract}
Lately, the moral condition of the younger generation is very worrying, where some of them have dared to do immoral act, thus damaging their moral. They have dared to violate the values, norms and rules of religion and government. For this reason the need for moral development of the younger generation, especially coaching through Islamic Religious Education. Islamic Religious Education is a powerful tool to overcome all problems, including the moral problems of the younger generation.
\end{abstract}

Keywords : Islamic education, moral, young generation.

\section{PENDAHULUAN}

Pada akhir-akhir ini keadaan moral generasi muda sungguh menghawatirkan, karena di sebagian mereka sudah berani melakukan asusila. Mereka sudah banyak yang terlibat minum-minuman keras, pergaulan bebas, terlibat dalam narkoba dan perkelahian diantara mereka. Hal ini disertai dengan tindakan-tindakan yang mengganggu ketenangan dan ketertiban di tengah masyarakat.

Manusia itu dilahirkan dalam keadaan fitrah (suci) dan tidak mengetahui apapun, kemudian Allah swt,menugaskan manusia agar mau untuk mencari tahu apa yang ada di sekitarnya serta mau mempelajari setiap perubahan-perubahan yang terjadi melalui panca indra.

Sudah seharusnya sebagai generasi muda agar untuk menerapkannya pada kehidupan sehari-hari dan mencintai setiap proses yang terjadi. Sehingga sejak dini sudah tercipta suatu karakter individu yang bisa menghadapi hambatanhambatan yang suatu saat pasti akan terjadi. 
67 | MUSAWA, Vol. 11 No. 1 Juni 2019 : 66 - 80

Disisi lain keberadaan generasi muda sangat diharapkan oleh bangsa dan agama kedepan ditangan merekalah masa depan bangsa dan agama dititipkan.

Mengingat keadaan generasi muda ini semakin hari semakin mencemaskan, maka butuh penanganan yang serius karena mereka adalah harapan bangsa dan agama di masa yang akan datang, dan untuk mengobati penyakitpenyakit yang diderita oleh generasi muda ini, maka pendidikan agama Islam akan menawarkan ketenangan hidup yang sejati yang bersumber dari Allah sebagai segala sumber nikmat dan ketenangan dalam hidup.

Pentingnya pendidikan agama Islam pada generasi muda yaitu untuk mewujudkan cita-cita masyarakat indonesia terlebih yang beragama Islam sesuai dengan perintah Allah Swt. dan menanamkan Akhlakul Karimah sebagai bekal menuju jalan yang telah disiapkan oleh Allah swt. untuk hamba-hambanya yang mau dengan ikhlas belajar sesuai dengan ajaran Islam.

Olehnya itu dalam tulisan ini akan dibahas lebih lanjut tentang peranan pendidikan agama dalam pembinaan moral generasi muda sekarang.

\section{PEMBAHASAN}

\section{KEADAAN MORAL GENERASI MUDA SAAT INI}

Masa depan suatu bangsa sangat ditentukan oleh generasi muda yang saat ini sedang tumbuh. Pemuda adalah pemimpin masa depan, oleh karena itu pendidikan karakter bagi generasi muda menjadi sangat penting dan harus terus menerus dilakukan oleh semua pihak demi harapan dan masa depan bangsa Indonesia. Generasi muda yang saat ini sedang menyerap berbagai macam ilmu pengetahuan menjadi harapan besar bagi kuatnya bangsa dan negara Indonesia. ilmu yang diperoleh dari berbagai sumber seperti buku-buku, internet, serta media-media lain dalam pendidikan formal, pendidikan informal, maupun nonformal tidak akan berarti apa-apa tanpa diimbangi dengan pendidikan moral. Sehubungan dengan hal tersebut, moralitas bangsa masih dapat diselamatkan dan ditumbuh-kembangkan melalui proses pendidikan. Proses pendidikan tidak sekadar diarahkan pada pengetahuan, tetapi juga diarahkan pada pembentukan 
Narjun Bahmid, Peranan Pendidikan Agama ... $\mid 68$

moral yang mencerminkan nilai-nilai luhur yang tertanam dalam diri generasi muda.

Menurut Zakiah Daradjat (1982), bahwa yang dimaksud generasi muda adalah mencakup umur anak dan remaja, mulai dari segala segi (jasmani, rohani, sosial budaya dan ekonomi). ${ }^{1}$ Sedangkan menurut Instruksi Presiden RI. No. 12 tahun 1982, bahwa yang dimaksud generasi muda ialah bagian dari suatu generasi yang berusia 0-30 tahun. ${ }^{2}$

Generasi muda yang dimaksud dalam tulisan ini adalah generasi muda yang berumur 12-30 tahun, yaitu generasi yang mulai menginjak masa remaja sampai mencapai kemtangan umur sampai mencapai kematangan umur untuk memasuki masa dewasa.

Umur 12-30 tahun ini yang merupakan umur yang relatif belum seimbang, karena pengaruh perkembangan jasmani dan rohaninya. Oleh karena itu umurumur seperti ini berpeluang untuk melakukan tindakan-tindakan yang melanggar norma. Jika tidak diarahkan dan dibina dengan baik oleh lingkungannya.

Hal ini terlihat pada akhir-akhir ini, umur-umur anak yang berusia 12-30 tahun terjadi suatu kenakalan-kenakalan yang bisa mengakibatkan rusaknya moral dikalangan mereka. Dimana minuman keras, narkotika, pergaulan bebas dan kenakalan-kenakalan lainnya menjadi kebanggaan di kalangan mereka terutama yang berusia remaja.

Menurut Zakiah Daradjat, bahwa kenyataan yang sangat mencemaskan belakangan ini ialah keberanian, sementara remaja melakukan pelanggaran asusila baik pria maupun wanita. Bahkan diantara mereka ada yang berpendapat bahwa hubungan antara pria dan wanita tak perlu dibatasi oleh orang tua. Biasa kenakalan seperti ini disertai dengan tindakan yang mengganggu ketentraman masyarakat. ${ }^{3}$

Akibat-akibat keberanian genersi muda melakukan tindakan asusila di tengah-tengah masyarakat, maka moral mereka semakin hari semakin merosot.

${ }^{1}$ Zakiah Daradjati, Ilmu Jiwa Agama, (Cet.XIV; Jakarta: Bulan Bintang, 1982).

${ }^{2}$ Abdullah Nasih Ulwan, Dasar-dasar Pembinaan Pendidikan dan Pengembangan Generasi Muda, (Jakarta: Dharma Bakti, 1982).

${ }^{3}$ Zakiah Daradjati, Perawatan Jiwa Anak-Anak, (Jakarta: Bulan Bintang, 1973). 
69 | MUSAWA, Vol. 11 No. 1 Juni 2019 : 66 - 80

Kemerosotan moral generasi muda ini diperparah lagi oleh adannya pengaruh kebudayaan Barat yang sangat bertentangan dengan nilai-nilai yang berkembang di masyarakat Indonesia.

Menurut Zakiah Daradjat, mengatakan bahwa kalau saja alat-alat penggiur dan pembangkit hawa nafsu itu hanya terbatas pada alat permainan maksiat atau cara-cara untuk mempermudah hubungan kelamin yang terkutuk itu, tentu akan ringan musibah yang menimpa kita, akan tetapi disamping itu, terdapatlah malapetaka yang lebih mengerikan lagi, lebih buruk akibatnya, lebih gampang penularannya yaitu apa-apa yang dibawa oleh peradaban Barat dengan berbagai macam teori kejahatan dan contoh-contoh perbuatan maksiat yang meresap, menyelinap ke dalam jiwa para generasi muda, laksana meresapnya air dingin ke dalam tenggorokan orang yang haus ketika dahaga yang tak tertahankan. ${ }^{4}$

Demikian keadaan moral generasi muda sekarang ini, mereka melakukan pelanggaran-pelanggaran asusila, karena disebabkan kurangnya perhatian dan pendidikan terutama pendidikan agama. Pendidikan agama sebenarnya perlu ditanamkan sama anak sedini mungkin karena pendidikan agama merupakan modal yang utama untuk menangkal semua masalah termasuk masalah moral yang dialami oleh generasi muda sekarang.

\section{PENTINGNYA PEMBINAAN MORAL BAGI GENERASI MUDA}

Persepektif moral dalam Islam merupakan moral yang berdasarkan pada kepercayaan terhadap Tuhan dan kehidupan akhirat sesuai dengan konsep moral yang bersifat keagamaan yang ditentukan oleh bentuk gagasan manusia mengenai Tuhan dalam kehidupan. Adapun Moral dalam Islam adalah bersifat absolut dan universal. Kebenaran moral Islam bersifat mutlak, mempunyai wujud dan bentukbentuk tertentu. Humaidi Tatapangarsa menyatakan bahwa Moral dalam Islam adalah menjauhi dunia dan mengutamakan akhirat, dengan tujuan memanfaatkan hal-hal yang di dunia ini untuk kebahagiaan hidup kekal di akherat. ${ }^{5}$ 
Narjun Bahmid, Peranan Pendidikan Agama ... $\mid 70$

Akhlaq adalah mustika hidup yang membedakan manusia yang diciptakan Tuhan dengan makhluk yang lain. Dengan ilmu pengetahuan, memang, dalam batas-batas tertentu, bisa mengetahui yang baik dan yang buruk. Menurut Hasan Basri, akhlaq merupakan sesuatu yang mempunyai taraf kesadaran yang tinggi, mempunyai motivasi yang kuat, mempunyai tanggung jawab yang besar. Oleh sebab itu, pemuda harus mempunyai sifat-sifat jujur, adil, disiplin yang tinggi, amanah, taat, berani menegakkan kebenaran dan memperjuangkannya. Dalam situasi dan kondisi kemajuan ilmu pengetahuan dan teknologi, serta tuntutan dari pembangunan, di kalangan generasi muda perlu dikembangkan rasa percaya pada diri sendiri, profesionalisme, kewirausahaan, dan kreativitas. Seperti dinyatakan oleh Carl Roger bahwa inti kreativitas itu adalah "Baru" dengan cirinya yang cerdas, menarik dan imajinatif, di samping juga cepat, fleksibel dan prospektif, efektif dari segi sosial serta dominan dari segi pribadi. ${ }^{6}$

Era Globalisasi yang ditandai dengan persaingan kualitas atau mutu, menuntut semua pihak dalam berbagai bidang dan sektor pembangunan untuk senantiasa meningkatkan kompetensinya. Hal tersebut mendudukkan pentingnya upaya meningkatkan kualitas pendidikan baik secara kuantitatif maupun kualitatif yang harus dilakukan terus-menerus. Dengan demikian, pendidikan, terutama pendidikan Islam, dapat digunakan sebagai wahana dalam membangun watak bangsa.

Pembinaan moral generasi muda dapat dilakukan melalui pembinaan budaya religius yang ada di lembaga pendidikan yang biasanya bermula penanaman nilai-nilai religius secara istiqomah. Begitu juga penciptaan suasana religius dan mengadakan kegiatan keagamaan di lingkungan lembaga pendidikan. Apabila tidak diciptakan dan dibiasakan, maka budaya religius tidak akan terwujud. Kegiatan-kegiatan yang dapat menumbuhkan budaya religius (religious culture) di lingkungan lembaga pendidikan meliputi; pertama, melakukan kegiatan rutin, yaitu pengembangan kebudayaan religius yang berlangsung pada

${ }^{6}$ Hasan Basri, Remaja Berkwalitas (Problem dan Solisinya), (Yogyakarta: Pustaka Pelajar, 1995), h. 31. 
hari-hari belajar biasa di lembaga pendidikan. Kegiatan rutin tersebut dilakukan dalam kegiatan sehari-hari yang terintegrasi dengan kegiatan yang telah diprogramkan, sehingga tidak memerlukan waktu khusus. Pendidikan agama merupakan tugas dan tanggungjawab bersama bukan hanya guru agama saja melainkan juga tugas dan tanggungjawab guru-guru atau dosen-dosen bidang lainnya. Pendidikan agamapun tidak hanya terbatas pada aspek pengetahuan, tetapi juga meliputi pembentukan sikap, perilaku dan pengalaman keagamaan. Maka dari itu, pembentukan sikap, perilaku dan pengalaman keagamaanpun tidak hanya dilakukan oleh guru atau dosen agama, tetapi perlu juga dilakukan oleh guru atau dosen bidang studi lainnya.

Kedua, menciptakan lingkungan lembaga pendidikan yang mendukung dan menjadi laboratorium bagi penyampaian pendidikan agama, sehingga lingkungan dan proses kehidupan semacam ini bagi para peserta didik benar-benar bisa memberikan pendidikan tentang cara belajar beragama. Dalam proses tumbuh kembangnya, peserta didik dipengaruhi oleh lingkungan lembaga pendidikan, selain lingkungan keluarga dan lingkungan masyarakat. Suasana lingkungan lembaga pendidikan dapat menumbuhkan budaya religius (religious culture). Lembaga pendidikan mampu menanamkan sosialisasi dan nilai yang dapat menciptakan generasi-generasi yang berkualitas dan berkarakter kuat, sehingga menjadi pelaku-pelaku utama kehidupan di masyarakat. Suasana lingkungan lembaga ini dapat membimbing peserta didik agar mempunyai akhlak mulia, perilaku jujur, disiplin, dan semangat sehingga akhirnya menjadi dasar untuk meningkatkan kualitas dirinya.

Ketiga, pendidikan agama tidak hanya disampaikan secara formal dengan pelajaran agama dalam suatu proses pembelajaran, namun dapat pula dilakukan diluar proses pembelajaran dalam kehidupan sehari-hari. Guru atau dosen bisa memberikan pendidikan agama secara spontan ketika menghadapi sikap atau perilaku peserta didik yang tidak sesuai dengan ajaran agama. Manfaat pendidikan secara spontan akan menjadikan peserta didik langsung mengetahui dan menyadari kesalahan yang dilakukannya dan langsung mampu memperbaikinya. 
Keempat, menciptakan situasi atau kegiatan religius. Tujuannya untuk mengenalkan kepada generasi muda tentang pengertian agama dan tata cara pelaksanaan agama tersebut dalam kehidupan sehari-hari. Juga menunjukkan pengembangan kehidupan religius di lembaga pendidikan yang tergambar dari perilaku sehari-hari. Selain itu juga menunjukkan pengembangan kehidupan religius di lembaga pendidikan yang tergambar dari perilaku sehari-hari dari berbagai kegiatan yang dilakukan oleh guru atau dosen dan pemuda. Oleh karena itu, keadaan atau situasi keagamaan di sekolah atau kampus yang dapat diciptakan antara lain pengadaan peralatan peribadatan seperti tempat untuk sholat (masjid atau musholla), alat-alat sholat seperti sarung, peci, mukena, sajadah atau pengadaan al-Quran. Di ruangan kelas bisa pula ditempelkan kaligrafi, sehingga peserta didik dibiasakan selalu melihat sesuatu yang baik.

Kelima, memberikan kesempatan kepada peserta didik sekolah maupun universitas untuk mengekspresikan diri, menumbuhkan bakat, minat dan kreativitas pendidikan agama dalam ketrampilan dan seni, seperti membaca alQuran, adzan, sari tilawah serta mendorong generasi muda untuk mencintai kitab suci, dan meningkatkan minat para pemuda untuk membaca, menulis serta mempelajari isi kandungan al-Quran. Agar lebih jelas dalam membahas materi pelajaran maka guru maupun dosen hendaknya selalu diperkuat oleh nas-nas keagamaan yang berlandaskan pada al-Quran dan Hadist Rasulullah saw, tidak hanya ketika mengajar saja tetapi dalam setiap kesempatan guru atau dosen harus mengembangkan kesadaran beragama dan menanamkan jiwa keberagaman yang benar. Oleh karena itu, guru maupun dosen harus mampu menciptakan dan memanfaatkan suasana keberagaman dengan menciptakan suasana dalam peribadatan seperti sholat, puasa dan lain-lain. ${ }^{7}$

${ }^{7}$ Muhaimin, Arah Baru pengembangan Pendidikan Islam, Pemberdayaan, pengembangan kurikulum Hingga Redinivisi Islamisasi Pengetahuan, (Bandung: Nuansa, 2003), h. 69. 
73 | MUSAWA, Vol. 11 No. 1 Juni 2019 : 66 - 80

\section{PERANAN PENDIDIKAN AGAMA ISLAM DALAM PEMBINAAN MORAL GENERASI MUDA}

Kemerosotan moral yang menghinggapi remaja saat ini seakan-akan merupakan kegagalan lembaga pendidikan untuk membentuk karakter yang beradab menuju Indonesia bermartabat Sekolah sebagai lembaga pendidikan tidak akan lepas dari tudingan masyarakat jika ada penyimpangan moral dari remaja. Padahal penanaman moral pada remaja terdapat pada semua elemen mulai dari keluarga, sekolah, dan masyarakat. Kalau dikaji secara detail, penyebab kemerosotan moral pada diri anak bukan hanya karena adanya penurunan akhlak dan kurangnya pemahaman terhadap nilai agama atau pun nilai-nilai budi pekerti yang luhur. Bisa saja penyebab kemerosotan moral sering terjadi karena kurangnya perhatian orang tua sehingga anak merasa terabaikan. Penyebab lain yang besar peranannya terhadap kemerosotan moral remaja adalah perkembangan zaman atau pengaruh globalisasi yang telah masuk ke Indonesia. Banyak dampak negatif yang terbawa, di samping dampak positif yang menyertainya.

Masalah pendidikan merupakan masalah universal yang menyangkut pada semua elemen dalam kehidupan berbangsa dan bernegara. Karena pendidikan sebenarnya merupakan kebutuhan pokok dalam melangsungkan dan mempertahankan kehidupan dalam kehidupan manusia, pendidikan merupakan salah satu aspek penting dalam membentuk generasi mendatang, dengan demikian pendidikan diharapkan dapat menghasilkan manusia berkualitas, bertanggung jawab dan mampu mengantisipasi masa depan.

Pendidikan dalam makna yang luas senantiasa menstimulir menyertai perubahan-perubahan dan perkembangan umat manusia. Selain itu, upaya pendidikan senantiasa mengantar, membimbing perubahan dan perkembangan hidup serta kehidupan umat manusia.

Dilihat dari konsep dasar penciptaannya, manusia merupakan makhluk Tuhan yang diberikan amanah sebagai khalifah dimuka bumi, hal ini tersirat dalam firman Allah SWT dalam surat Al-Baqarah ayat 30: 


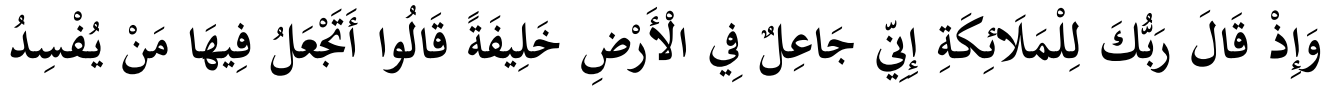

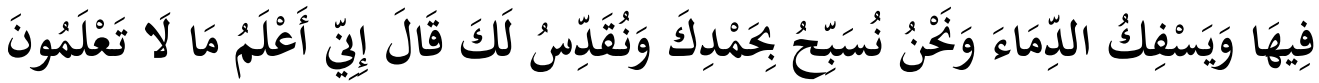

Terjemahnya:

"Ingatlah ketika tuhanmu berfirman kepada para malaikat. Sesungguhnya Aku hendak menjadikan seorang khalifah di muka bumi”. Mereka berkata "Mengapa engkau hendak menjadikan (kholifah) di bumi itu orang yang akan membuat kerusakan dan menumpahkan darah, padahal kami senantiasa bertasbih dengan menjadi engkau dan mensucikan engkau? "Tuhan berfirman: "Sesungguhnya aku mengetahui apa yang tidak kamu ketahui”.

Dari ayat di atas, pada hakekatnya tugas yang diemban oleh manusia sangat berat dengan kata lain yaitu sebagai khalifah, yakni khalifah seluruh umat. Oleh sebab itu, kenyataan ini merupakan sebuah tantangan yang menuntut untuk lebih berkiprahnya pendidikan Islam, terutama dalam upaya peningkatan dan pengembangan kualitas sumber daya manusia yang sekarang sedang gencargencarnya dikumandangkan.

Pendidikan agama dalam sistem pendidikan nasional tampaknya terdapat konsistensi dan keterkaitan langsung antara rumusan fungsi pendidikan agama dengan tujuan pendidikan nasional yang tertuang pada pasal 3 UU RI Nomor 20 tahun 2003 yaitu : "Pendidikan nasional berfungsi mengembangkan kemampuan dan membentuk watak serta peradaban bangsa yang bermartabat dalam rangka mencerdaskan kehidupan bangsa, bertujuan untuk berkembangnya potensi peserta didik agar menjadi manusia yang beriman dan bertaqwa kepada Tuhan Yang Maha Esa, berakhlak mulia, sehat, berilmu, cakap, kreatif, mandiri, dan menjadi warga Negara yang demokratis serta bertanggung jawab.

Dalam upaya membentuk manusia Indonesia yang beriman dan bertakwa, maka pendidikan agama memiliki peranan yang sangat penting. Untuk itulah maka pendidikan agama wajib diberikan pada semua satuan, jenjang dan jenis pendidikan, baik melalui jalur sekolah maupun jalur luar sekoah. 
Agama Islam adalah agama yang universal yang mengajarkan kepada umat manusia mengenai berbagai aspek kehidupan, baik duniawi maupun ukhrawi. Salah satu diantara ajaran Islam tersebut adalah mewajibkan kepada umat Islam untuk melaksanakan pendidikan, karena menurut ajaran Islam pendidikan adalah juga merupakan kebutuhan hidup manusia yang mutlak harus dipenuhi, demi untuk mencapai kesejahteraan dan kebahagiaan dunia dan akhirat. Dengan pendidikan itu pula manusia akan mendapatkan berbagai macam ilmu pengetahuan untuk bekal dan kehidupannya.

Tentang bagaimana jiwa dan kepribadian seorang anak serta bagaimana perkembangan selanjutnya, semua tergantung bagaimana cara kita memberikan pendidikan utamanya pendidikan agama sebagai modal kepribadian. Zuhairini menerangkan bahwa fitrah beragama pada manusia telah dibawa sejak lahirnya, maka fitrah tersebut akan berkembang dengan adanya pendidikan. Karena adanya fitrah beragama itu maka manusia disebut homo dinivans (makhluk berketuhanan) atau juga disebut sebagai homo religius (makhluk beragama), karena dengan adanya agama manusia akan mendapatkan ketentraman lahir dan batin.

Manusia pada hakekatnya mempunyai kebebasan dalam menentukan perjalanan hidupnya dalam ajaran Islam memang terdapat kebebasan yang seluasluasnya bagi manusia untuk melakukan sesuai dengan kehendaknya baik dalam bidang ekonomi, politik, maupun dalam bidang sosial. Kebebasan yang diberikan Allah kepada umat Islam bukan berarti lepas sama sekali dari norma-norma agama dan norma-norma sosial, melainkan kebebasan yang memiliki yang bertanggung jawab dengan apa yang telah menjadi keputusan.

Agama dan norma-norma sosial menjadi suatu tolak ukur dalam semua kehidupan, sudah terkikis oleh pola kehidupan yang terjadi pada saat sekarang ini. Hal ini dikarenakan minimnya organisasi keagamaan, kesadaran orang tua terhadap pentingnya pendidikan agama dan minimnya perhatian mesyarakat akan tingkah laku remaja.

Di dalam pendidikan Islam ada beberapa hal yang menjadi tumpuan antara aqidah, ibadah dan akhlak dengan semua ini diharapkan nantinya generasi penerus dalam tingkah lakunya mengandung nilai-nilai keislaman. 
Mengingat keadaan moral generasi muda semakin hari semakin rusak, maka diperlukan penanganan yang serius dari semua pihak mereka perlu pembinaan, terutama pembinaan mental keagamaannya.

Menurut Zakiah Daradjat, bahwa pendidikan agama merupakan alat pembinaan yang sangat ampuh bagi generasi muda, agama yang tertanam dan bertumbuh secara dalam jiwa generasi muda akan dapat digunakannya untuk mengendalikan keinginan-keinginan dan dorongan-dorongan yang kurang baik serta membantunya dalam menghadapi berbagai masalah kehidupan pada umumnya. Dengan hidup segarnya keyakinan agama dalam diri generasi muda, akhlaknya dengan sendirinya akan baik. Karena kontrolnya datang dari dalam, bukan dari luar. Kesukaran yang dihadapinya dapat diatasinya, ia dapat berdoa, mengeluh dan berdialog langsung dengan Tuhannya. ${ }^{8}$

Pendidikan agama merupakan alat yang paling ampuh dalam menghadapi berbagai masalah. Oleh karena itu perlu ditanamkan sedini mungkin kepada generasi muda agar mereka bisa selamat dalam menghadapi berbagai macam masalah hidupnya. Pendidikan agama yang ditanamkan pada mudanya merupakan modal bagi mereka untuk kehidupan selanjutnya.

Dalam rangka pembinaan generasi muda, khususnya dibidang agama, maka dituntut dari berbagai pihak untuk saling kerja sama dalam mengatasi penyakitpenyakit yang telah diderita oleh generasi muda. Dari itu merupakan kewajiban berbagai pihak untuk membinanya agar generasi muda bisa selamat dari masa mudanya.

Menurut Yusuf Qardhawi, bahwa pembinaan generasi muda merupakan beban utama bagi para da'i, ahli pikir, fuqaha dan cendekiawan muslim, para pakar inilah yang harus bergotong royong mempersiapkan mereka dengan sebaikbaiknya. Usaha yang paling utama ialah mendidiknya dengan pendidikan yang saling melengkapi yakni pendidikan rohani, jasmani, intelektual, moral, sosial dan 
politik. Mereka harus senantiasa melindungi generasi ini dari erosi baik dari dalam maupun dari luar generasi muda itu sendiri. ${ }^{9}$

Untuk membina generasi muda ini diperlukan para pendidik yang ikhlas dan bijaksana. Para pendidik tidak boleh membiarkan generasi muda terlunta-lunta dalam rasa kecemasan dan kebingungan, ia harus menunjukkan pengertian akan rasa hati generasi muda yang cemas dan tidak aman itu. Seorang pendidik yang baik selalu menuntun generasi pada harapan-harapan baru dalam ajaran agama. Dia akan membantu dalam pertumbuhan generasi muda kearah yang lebih baik dan mampu menghadapi hidup dengan tenang dan penuh harapan, karena adannya Allah Yang Maha Pengasih akan memberi petunjuk dalam menghadapi hidup dan kehidupan ini, sehingga terasa akan dihargai, disayangi dan dikasihi oleh Allah SWT. ${ }^{10}$

Dalam pembinaan generasi muda ini, yang tidak kalah pentingnya adalah peranan orang tua, bahkan pendidikan agama dari orang tua yang diterimanya sejak kecil itulah sebagai bekal utnuk dikembangkan pada lingkungan sekolah dan masyarakat. Di masyarakat dan sekolah hanya melanjutkan pendidikan yang diterima dari orang tuannya.

Menurut Soekanto, bahwa lingkungan pertama yang berhubungan dengan anak adalah orang tuannya, saudara-saudara serta sanak kerabatnya dari lingkungan keluargalah anak-anak mulai bersosialisasi baru dengan lingkungan lainnya. ${ }^{11}$

Menurut Zakiah Daradjat, bahwa lingkungan keluarga sangat berpengaruh dalam pembentukan kepribadian anak. Pendidikan agama yang di dapat anak di keluarga merupakan modal awal bagi anak untuk dikembangkan kepada lingkungan sekolah dan masyarakat. Di masyarakatlah dan sekolah hanya melanjutkan pendidikan yang diterima dari orang tuanya dan jangan sebaliknya orang tua mengharapkan sekolah sebagai satu-satunya untuk diserahkan tugas

\footnotetext{
${ }^{9}$ Yusuf Qordhowi, Generasi Mendatang Generasi Menang, (Jakarta: Gema Insani Press, 1991).

${ }^{10}$ Abdullah Nasih Ulwan, Pesan untuk pemuda Islam, (Cet.I; Jakarta: PT. Gema Insan Press, , 1991).

${ }^{11}$ Soerjono Soekanto, Teori Sosiologi tentang Perubahan Sosial, (Jakarta: Ghalia Indonesia, 1990).
} 
untuk mendidikan anak-anaknya, sehingga kalau ada kenakalan anak-anaknya sekolah disalahkan. Harus disadari oleh orang tua bahwa orang tualah yang pertama-tama yang berkewajiban untuk mendidik anak-anaknya dan sekolah hanyalah sebagai yang melanjutkan pendidikan dari orang tuanya. ${ }^{12}$

Selanjutnya lingkungan yang berpengaruh dalam membentuk moral generasi muda adalah sekolah. Sekolah merupakan lingkungan kedua setelah anak di lingkungan keluarganya. Sekolah dalam hal ini guru harus memberikan pembinaan keagamaan kepada murid-muridnya agar pendidikan agama yang diterima anak-anak di rumah bisa sejalan dengan pendidikan agama di sekolahnya. Demikian juga sekolah harus tetap menciptakan suasana religius agar anak terjaga ketentraman batinnya.

Menurut Zakiah Daradjat, bahwa menciptakan kondisi islamic di sekolah akan membuat jiwa anak-anak semakin kuat dalam menghadapi tantangan hidupnya. Guru harus berperan dan tetap berpegang teguh pada ajaran-ajaran agama serta berakhlak mulia, berbudi luhur, pengasih dan penyayang pada siswisiswinya. Guru jangan bertindak sebagai pengajar saja, tetapi hendaklah menjadi seorang pendidik sekaligus sebagai konsultan bagi anak didiknya. ${ }^{13}$ Dan lingkungan yang ketiga yang harus berperan membentuk moral generasi muda adalah lingkungan yang sangat berpengaruh bagi pembentukan moral generasi muda, karena generasi muda lebih banyak waktunya utnuk berinteraksi antar sesama di lingkungan masyarakatnya. Olehnya itu masyarakat harus senantiasa menjaga dan mengembangkan nialai-nilai agama agar generasi muda terjaga ketentraman bathinnya.

Akhlak tidak akan tumbuh tanpa diajarkan dan dibiasakan. Oleh sebab itu pendidikan agama, selain sebagai ilmu secara bertahap juga harus diikuti secara terus menerus bentuk pengalamannya. Orang tua memegang peranan penting dalam pelaksanaan pendidikan agama dirumah. Namun orang tua diharapkan menjadi teladan dalam beribadah dan berakhlak. Begitu juga dengan tokoh

${ }^{12}$ Zakiah Daradjat, Membina Nilai-Nilai Moral di Indonesia, (Cet. IV: Jakarta: Bulan Bintang, 1985).

${ }^{13}$ Zakiah Daradjat, Pendidikan Agama dan Pembinaan Jiwa atau Mental, (Cet. I; Jakarta: Bulan Bintang, 1979). 
79 | MUSAWA, Vol. 11 No. 1 Juni 2019 : 66 - 80

masyarakat, juga memiliki peranan penting dalam pendidikan agama di masyarakat. Aktivitas keagamaan yang menunjol dimasyarakat akan menarik pemuda untuk ambil bagian didalam aktivitas tersebut. Jadi keberhasilan pendidikan agama tidak hanya menjadi tanggung jawab guru agama, tetapi menjadi tanggung jawab semua pihak. Oleh karena itu menjadi tugas semua pihak untuk meningkatkan moral dan akhlak remaja sebagai modal keberhasilan pembangunan bangsa indonesia dalam memasuki dunia globalisasi, yang serat dengan tantangan akan rusaknya moralitas bangsa.

Menurut T. O'dea, bahwa fungsi agama pada suatu masyarakat adalah sangat penting. Agama merupakan kebutuhan fungsional dari semua masyarakat. Olehnya pendidikan agama merupakan kebutuhan fungsional bagi semua masyarakat. Agama memberi landasan moral bagi masyarakatnya. Dengan tumbuh suburnya nilai-nilai agama di masyarakat, maka akan membantu masyarakat, khususnya generasi muda terjamin ketentraman bathinnya. Suasana keagamaan seperti inilah yang perlu diciptakan oleh masyarakat agar generasi mudanya selamat dari masa mudanya dan jauh dari penyakit-penyakit sosial yang bisa membahayakan bagi masa depan generasi muda itu sendiri. ${ }^{14}$

Dengan demikian dapat dikatakan bahwa untuk mengobati penyakitpenyakit sosial yang dialami oleh generasi muda sekarang, maka pendidikan agama merupakan landasan pokok dalam pembinaan generasi muda karena pendidikan agama merupakan alat yang ampuh untuk mengatasi semua masalah, termasuk masalah yang dihadapi oleh generasi muda sekarang ini. Dan disamping itu kerja sama dari berbagai pihak sangat perlu, baik pihak keluarga, sekolah maupun masyarakat itu sendiri. Karena tiga lingkungan itu sangat berpengaruh pada pembentukan moral generasi muda dalam kehidupan mereka sehari-harinya.

\section{KESIMPULAN}

Keadaan moral generasi muda pada akhir-akhir ini sungguh mencemaskan bagi semua pihak. Karena mereka berani melakukan tindakan asusila dan

${ }^{14}$ F. O'dea, Thomas, Sosialogi Agama, (Jakarta: PT. Raja Wali Press, 1996). 
melanggar nilai dan norma agama dan budaya bangsa sehingga mengakibatkan menurunnya moral diantara mereka.

Untuk mengatasi menurunnya moral generasi muda ini maka perlu adanya pembinaan, utamanya pembinaan dibidang agama. Pendidikan Agama Islam adlah alat yang ampuh untuk mengatasi semua masalah, termasuk mengatasi keadaan moral generasi muda.

\section{DAFTAR PUSTAKA}

Abdullah Nasih Ulwan. 1991. Pesan Untuk Pemuda Islam, Cet.I; PT. Gema Insan Press: Jakarta. 1982. Dasar-dasar Pembinaan Pendidikan dan Pengembangan Generasi Muda; Dharma Bakti: Jakarta.

Harmaidi Tatapangarsa, Pengantar Kuliah Akhlaq, Surabaya: Bina Ilmu, 1990.

Hasan Basri, Remaja Berkwalitas (Problem dan Solisinya), Yogyakarta: Pustaka Pelajar, 1995.

Muhaimin, Arah Baru pengembangan Pendidikan Islam, Pemberdayaan, pengembangan kurikulum Hingga Redinivisi Islamisasi Pengetahuan, Bandung: Nuansa, 2003.

Soerjono Soekanto. 1990. Teori Sosiologi tentang Perubahan Sosial; Ghalia Indonesia: Jakarta.

Thomas F. O’dea. 1996. Sosialogi Agama; PT. Raja Wali Press: Jakarta.

Yusuf Qordhowi. 1991. Generasi Mendatang Generasi Menang; Gema Insani Press: Jakarta.

Zakiah Daradjat. 1992. Ilmu Jiwa Agama, Cet.XIV; Bulan Bintang: Jakarta. 1973. Perawatan Jiwa Anak-Anak; Bulan Bintang: Jakarta. 1982. Pembinaan Remaja, Cet.IV; Bulan Bintang: Jakarta. . 1985. Membina Nilai-Nilai Moral di Indonesia, Cet. IV; Bulan Bintang: Jakarta. 1979. Pendidikan Agama dan Pembinaan Jiwa atau Mental, Cet.

I; Bulan Bintang: Jakarta. 